\title{
Effect of Pre-Sowing Treatments, Sowing Positions and Age of Stones after Extraction on Germination of Mango
}

\author{
U.R. Reshma*and S. Simi \\ Department of Pomology and Floriculture, College of Agriculture, Vellayani, \\ Thiruvananthapuram, Kerala -695522, India \\ *Corresponding author
}

\section{A B S T R A C T}

\begin{tabular}{|c|}
\hline Keywords \\
\hline $\begin{array}{l}\text { Mango stones, } \\
\text { Sowing positions, } \\
\text { Age, Pre sowing } \\
\text { Treatments, } \\
\text { Germination }\end{array}$ \\
\hline Article Info \\
\hline $\begin{array}{l}\text { Accepted: } \\
17 \text { March } 2019 \\
\text { Available Online: } \\
10 \text { April } 2019\end{array}$ \\
\hline
\end{tabular}

\section{Keywords}

Mango stones, Sowing positions,

\section{Introduction}

Mango is commercially propagated by veneer, stone, approach and softwood grafting in different parts of the India. In most of the fruit crops, rootstock influences the vigour, longevity, tree size, yield and quality. For successful graft union, it is imperative to have healthy, strong and actively growing rootstocks. Mango stones are usually available during the drier parts of the year (April-May) because of which the germination percentage and vigour were found to be very low (Kolekar et al., 2017). The viability of mango stones are low because of its recalcitrant nature. Germination percentage of mango stone is only 12 to 50 per cent when sown within a month of extraction. Pre-sowing treatments with chemicals viz., gibberellic acid $\left(\mathrm{GA}_{3}\right)$ and $\mathrm{KNO}_{3}$ have a significant effect on initiation of germination, boosting up of growth and vigour stimulation. Pre sowing treatments also protect seeds from biotic and abiotic factors during critical phase of seedling establishment. Synchronization and rapid 
seedling emergence are the commonly reported benefits of pre-sowing treatments on germination. The orientation of seeds on seed bed has a great role in boosting up of the process of germination. It has a positive influence on altering the energy levels which are needed for the radicle and plumule emergence required for completion of germination process. This is mainly due to the quantity of stored nutrients as well as the positioning of micropyle. The stalk end up position of sowing helps to place the micropyle in the most appropriate position and resulted in minimum requirement of energy for germination and stimulates the metabolic process that release energy for radicle emergence (Bewley, 1997). Age of stone also has a crucial impact on germination and subsequent growth. Moisture content is the key factor that determines the viability of recalcitrant seeds. Loss of critical moisture content as the age advances can cause the alterations in a series of metabolic processes and can cause accumulation of free radicals, which results in onset of the deterioration process (Patil and Krishna, 2016).

An experiment was therefore undertaken to assess the effect of pre-sowing treatments, sowing positions and age of stones after extraction from the fruit with the main objectives of increasing germination percentage and producing vigorous rootstocks in order to meet the ever rising market demand and to evolve the best technology for producing high quality mango planting material in a short period of time. The study aims to obtain information about seed germination and seedling development that could facilitate nursery production of mango seedlings for orchard establishment.

\section{Materials and Methods}

The present study was carried out during 2017 - 2018 at the College of Agriculture, Vellayani, Thiruvananthapuram. The experiment was laid out in Factorial Completely Randomized Block Design with 42 treatments. The treatments comprise of different combinations of 2 sowing positions (flat and stalk end up), 3 different age group of stones after extraction from fruit (freshly extracted stones, 10 days after extraction, and 20 days after extraction) and 7 pre-sowing treatments, $\mathrm{GA}_{3}-100$ and $200 \mathrm{ppm}, \mathrm{KNO}_{3}-1$ and 2 ppm, cow dung slurry, water and control. Fruits of 'Kotookonam Varikka' variety of mango were selected for stone extraction and were procured from southern tracts of Thiruvananthapuram, district of Kerala. The stones were washed thoroughly to remove extraneous material adhering to it. These stones were immersed in water and allowed to settle at the bottom of the container. Stones floating on the surface of water were discarded and those which settled at the bottom were used for experimentation. The mango stones were soaked in the above solutions for 24 hours prior to sowing during different times after extraction based on age groups. The resultant forty two treatments were replicated thrice. Treated mango stones of different age groups were sown in two different methods viz., stalk end up and flat positions.

The germination percentage was calculated using the formula given below;

Germination percentage $=$

Number of germinated stones x 100 Total stones

The rate of germination was determined by dividing the germination percentage with number of days taken for attaining the germination. The seedling vigour index-I was calculated by multiplying germination $\%$ and seedling length, while the seedling vigour index II was determined by multiplying germination $\%$ and dry weight of seedling. 
Five mango seedlings were selected at random from each replication for recording observations related to germination. The germination of stones started 15 days after sowing and continued upto 55 days. Observations were recorded daily for germination parameters and vegetative parameters like seedling length, dry weight and seedling vigour index I \& II were recorded 4 months after sowing. The experimental data recorded were subjected to statistical analysis as per the method suggested by Panse and Sukhatme (1967). Treatment means were separated using F test values at $5 \%$ level of significance.

\section{Results and Discussion}

Significant differences were observed among the pre-sowing treatments, sowing positions and age of stones after extraction from the fruit for germination characters. Statistically analysed results are given in Table 1 and 2 and are explained under following subheadings.

\section{Effect of sowing positions}

There was a significant impact of sowing positions on all the parameters chosen for this investigation (Table 1). The stones which were sown in stalk end up position stalk end up position resulted in the highest germination, minimum number of days for initiation of germination, high rate of germination and seedling vigour indices (on growth and weight basis). Sowing of seeds at proper depth and position was one of the most important nursery operations because it affects germination and subsequent growth. To ensure good germination, rapid emergence and good performance, seeds must be placed in a position and in an environment that ensures the availability of nutrients and water from the soil. Seed orientation affects seedling emergence greatly. The results are in conformity with Garner and Chaudhri (1976) and Hammed et al., (2014) in cashew. Germination commences with the uptake of water by the dry seed (imbibition) and is completed when embryonic shoot and root, i.e., plumule and radicle, respectively, emerged. The amount of energy required to accomplish this task varies with genotype and orientation of the seed at sowing because of the quantity of stored nutrients, especially endosperm and positioning of micropyle. Mango stones with stalk-end up places the micropyle in the most suitable position, i.e., pointing downward, and therefore requires less germination energy for the radicle to emerge from the embryo. Moreover, stalk-end facing up might enhance accessibility to required oxygen for the initial metabolic process that produces energy for radicle emergence (Bewley, 1997). Improper orientation of stones could deprive the emerging embryo of needed oxygen which could lead to high ethanol and pyruvate production in the system and finally death of the emerging embryonic (plumule and radicle) plants. This probably resulted in the reduced germination percentages and poor quantitative plant vigour.

\section{Effect of age of stones after extraction from the fruit}

The highest germination percentage, minimum number of days for initiation of germination, rate of germination, seedling vigour indices on growth basis and weight basis were the best for the freshly harvested stones (Table 1). Germination characteristics of freshly harvested stones were the best compared to other age group of stones (Chaudhari and Patel, 2012). Germination became progressively slower as the age advances. The highest germination percentage, minimum number of days for initiation of germination and for $50 \%$ germination, rate of germination, seedling 
length, dry weight of seedling, seedling vigour index- I and seedling vigour index- II were found best for the freshly harvested stones. The results are in conformity with Kumar et al., (2018b) in jamun.

\section{Effect of pre-sowing treatments}

The stones pre-treated with $\mathrm{GA}_{3} 100$ ppm recorded the highest germination, whereas $\mathrm{GA}_{3}(200 \mathrm{ppm})$ required minimum number of days for initiation of germination (Table 1). Early stone germination in $\mathrm{GA}_{3} 200$ ppm treatment might be due to increased endogenous auxin content due to application of $\mathrm{GA}_{3}$. The pre-soaking treatment of $\mathrm{GA}_{3}$ might have affected and altered the enzymatic reaction, protein synthesis and conversion of starch to sugars involved in the germination process (Paleg, 1960). Gibberellic acid induces denovo synthesis of proteolytic enzymes like $\alpha$-Amylase and ribonuclease. Amylases in turn hydrolyse starch in the endosperm, providing essential sugars for the initiation of growth processes and liberate chemical energy which is used in the activation of embryo as well as suppression of inhibition along with synthesis of RNA which resulted in higher germination (Copeland and Mcdonald, 1995). $\mathrm{GA}_{3}$ treatment is also known to over rule the photo dormancy, thermo-dormancy, dormancy imposed by incomplete embryo development, mechanical barriers and presence of germination inhibitors (Diaz and Martin, 1971). Similar results in case of $\mathrm{GA}_{3}$ were reported by Shaban (2010) in mango and Lay et al., (2013) in papaya

The highest rate of germination was observed in the treatment $\mathrm{GA}_{3} 200 \mathrm{ppm}$ followed by $\mathrm{GA}_{3} 100 \mathrm{ppm}$ and $\mathrm{KNO}_{3} 1 \mathrm{ppm}$ and the lowest in control. The difference in rate of germination may be attributed to the differential ability of the pre sowing treatment of these chemicals for reducing the time taken for germination and to remove the obstruction in embryo growth (Muralidhara et al., 2015). The stones treated with $\mathrm{GA}_{3} 200$ ppm took the least time for initiation and $50 \%$ of germination, while maximum days were reported in control. The variation with respect to the days required for potential germination might be due to the stimulative effect of chemicals on emergence of seedlings and the rate of different growth processes like cell elongation, cell division and cell multiplication (Patel et al., 2016).

Among the various treatments, the maximum seedling length was recorded in $\mathrm{GA}_{3} 200$ ppm followed by $\mathrm{KNO}_{3}(1 \%)$. This might be due to the fact that the $\mathrm{GA}_{3}$ stimulates vegetative growth by increased osmotic uptake of nutrients, cell multiplication and cell elongation which might have reflected in the maximum height of seedlings in this treatment. These results are in accordance with results obtained by Shalini et al., (1999) and Kumar et al., (2008a). The regulation of growth by gibberllins and $\mathrm{KNO}_{3}$ relates almost extensively to its stem elongation properties. Influence of gibberllic acid and potassium nitrate on stem elongation is achieved by inducing the cell wall extensibility, stimulating cell wall synthesis, reducing the rigidity of cell wall and by increasing cell division as well as increasing the synthesis of IAA leading to more growth.

Among the treatments, the highest dry weight was found in $\mathrm{GA}_{3} 200 \mathrm{ppm}$ followed by $\mathrm{KNO}_{3} 1 \mathrm{ppm}$ while the lowest was in control. The increased weight of seedling was mainly attributed to enhanced germination, early seedling emergence and better seedling growth. The higher vigour indices may be due to the higher germination percentage induced by these chemicals. Seedling Vigour Index is a product of germination percentage and seedling length. Higher the seedling vigour index, more vigorous the seedlings are considered to be (Abdul- Baki and Anderson, 1973). 
Table.1 Germination characters of mango as influenced by different sowing positions, age of stones after extraction from the fruit and pre-sowing treatments on germination of mango stones

\begin{tabular}{|c|c|c|c|c|c|c|c|c|}
\hline Parameters & $\begin{array}{c}\text { Days taken } \\
\text { for initiation } \\
\text { of } \\
\text { germination }\end{array}$ & $\begin{array}{c}\text { Days taken } \\
\text { for } 50 \% \\
\text { germination }\end{array}$ & $\begin{array}{l}\text { Germina } \\
\text { tion }(\%)\end{array}$ & $\begin{array}{c}\text { Rate of } \\
\text { germination }\end{array}$ & $\begin{array}{l}\text { Seedling } \\
\text { length } \\
(\mathrm{cm})\end{array}$ & $\begin{array}{l}\text { Dry weight } \\
\text { of seedling } \\
\text { (g) }\end{array}$ & $\begin{array}{l}\text { Seedling vigour } \\
\text { index -I } \\
\text { Growth basis } \\
(\mathbf{c m})\end{array}$ & $\begin{array}{c}\text { Seedling vigour } \\
\text { index- II } \\
\text { Weight basis } \\
\text { (g) }\end{array}$ \\
\hline \multicolumn{9}{|l|}{ Effect of sowing positions } \\
\hline Flat & 29.15 & 40.91 & 40.95 & 0.26 & 18.34 & 7.46 & $27.33 *(746.93)$ & $17.44 *(304.15)$ \\
\hline Stalk end up & 22.95 & 31.75 & 60.85 & 0.47 & 21.84 & 8.64 & $36.39 *(1324.23)$ & $22.84 *(521.67)$ \\
\hline $\mathbf{S E}(\mathbf{m})$ & 0.046 & 0.166 & 0.690 & 0.001 & 0.054 & 0.026 & 0.226 & 0.143 \\
\hline CD & 0.130 & 0.466 & 1.940 & 0.004 & 0.152 & 0.073 & 0.637 & 0.402 \\
\hline \multicolumn{9}{|c|}{ Effect of Age of stone after extraction from fruit } \\
\hline Freshly extracted stone & 18.56 & 31.29 & 59.84 & 0.47 & 22.76 & 8.60 & $36.80 *(1354.24)$ & $22.60 *(510.76)$ \\
\hline 10 days after extraction & 24.56 & 36.50 & 52.38 & 0.36 & 21.07 & 8.07 & $33.05 *(1092.30)$ & $20.45^{*}(418.20)$ \\
\hline 20 days after extraction & 35.03 & 41.20 & 40.48 & 0.28 & 16.45 & 7.48 & $25.74 *(662.55)$ & $17.37 *(301.72)$ \\
\hline $\mathbf{S E}(\mathbf{m})$ & 0.057 & 0.203 & 0.845 & 0.002 & 0.066 & 0.032 & 0.277 & 0.175 \\
\hline CD & 0.160 & 0.571 & 2.376 & 0.005 & 0.186 & 0.090 & 0.780 & 0.492 \\
\hline \multicolumn{9}{|l|}{ Pre sowing treatments } \\
\hline $\mathrm{GA}_{3}-100 \mathrm{ppm}$ & 23.89 & 33.94 & 62.59 & 0.43 & 21.16 & 8.47 & $36.37 *(1322.78)$ & $22.99 *(528.54)$ \\
\hline $\mathrm{GA}_{3}-200$ ppm & 22.62 & 31.78 & 55.19 & 0.47 & 22.69 & 9.58 & $35.30 *(1246.09)$ & $22.95 *(526.70)$ \\
\hline $\mathrm{KNO}_{3}-1 \mathrm{ppm}$ & 24.49 & 34.17 & 52.96 & 0.42 & 22.14 & 9.15 & $34.09 *(1162.13)$ & $21.92 *(480.49)$ \\
\hline $\mathrm{KNO}_{3}-2$ ppm & 25.69 & 35.56 & 50.00 & 0.36 & 20.14 & 8.00 & $31.60 *(998.56)$ & $19.85 *(394.02)$ \\
\hline Cow dung slurry & 25.78 & 35.78 & 55.19 & 0.35 & 19.94 & 7.64 & $33.10 *(1095.61)$ & $20.46 *(418.61)$ \\
\hline Water & 28.84 & 40.11 & 42.96 & 0.31 & 18.11 & 7.01 & $27.81 *(773.40)$ & $17.28 *(298.60)$ \\
\hline Control (no treatments) & 31.01 & 42.94 & 37.40 & 0.25 & 16.45 & 6.49 & $24.76 *(613.06)$ & $15.51 *(240.56)$ \\
\hline SE(m) & 0.087 & 0.310 & 1.291 & 0.003 & 0.101 & 0.049 & 0.424 & 0.267 \\
\hline CD at $5 \%$ & 0.244 & 0.872 & 3.630 & 0.008 & 0.285 & 0.137 & 1.192 & 0.751 \\
\hline
\end{tabular}


Table.2 Interaction effect of sowing positions, age of stones after extraction from the fruit and pre-sowing treatments on germination of mango stones

\begin{tabular}{|c|c|c|c|c|c|c|c|c|c|}
\hline $\begin{array}{l}\text { Sl. } \\
\text { no. }\end{array}$ & Treatments & $\begin{array}{l}\text { Days taken } \\
\text { for } \\
\text { initiation of } \\
\text { germination }\end{array}$ & $\begin{array}{l}\text { Days taken } \\
\text { for } 50 \% \\
\text { germination }\end{array}$ & $\begin{array}{c}\text { Germination } \\
(\%)\end{array}$ & $\begin{array}{c}\text { Rate of } \\
\text { germination }\end{array}$ & $\begin{array}{l}\text { Seedling } \\
\text { length } \\
\text { (cm) }\end{array}$ & $\begin{array}{c}\text { Dry } \\
\text { weight of } \\
\text { seedling } \\
\text { (g) }\end{array}$ & $\begin{array}{l}\text { Seedling vigour } \\
\text { index -I } \\
\text { Growth basis } \\
\text { (cm) }\end{array}$ & $\begin{array}{c}\text { Seedling vigour } \\
\text { index- II } \\
\text { Weight basis } \\
\text { (g) }\end{array}$ \\
\hline 1 & $\mathrm{~S}_{1} \mathrm{~A}_{1} \mathrm{~T}_{1}$ & 19.13 & 31.33 & 62.22 & 0.51 & 21.83 & 8.65 & $36.86 *(1358.60)$ & $23.22 *(538.50)$ \\
\hline 2 & $\mathrm{~S}_{1} \mathrm{~A}_{1} \mathrm{~T}_{2}$ & 17.73 & 30.33 & 53.33 & 0.58 & 23.92 & 9.60 & $35.69 *(1276.57)$ & $22.62 *(511.44)$ \\
\hline 3 & $\mathrm{~S}_{1} \mathrm{~A}_{1} \mathrm{~T}_{3}$ & 18.33 & 31.67 & 51.11 & 0.51 & 23.38 & 9.17 & $34.49 *(1191.39)$ & $21.634 *(469.13)$ \\
\hline 4 & $\mathrm{~S}_{1} \mathrm{~A}_{1} \mathrm{~T}_{4}$ & 21.00 & 33.67 & 46.67 & 0.40 & 21.41 & 7.88 & $31.58 *(999.91)$ & $19.17 *(367.49)$ \\
\hline 5 & $\mathrm{~S}_{1} \mathrm{~A}_{1} \mathrm{~T}_{5}$ & 22.20 & 33.33 & 53.33 & 0.41 & 20.10 & 7.70 & $32.73 *(1073.47)$ & $20.26 *(410.25)$ \\
\hline 6 & $\mathrm{~S}_{1} \mathrm{~A}_{1} \mathrm{~T}_{6}$ & 23.73 & 38.34 & 40.00 & 0.26 & 19.04 & 7.36 & $27.55 *(761.82)$ & $17.13 *(293.35)$ \\
\hline 7 & $\mathrm{~S}_{1} \mathrm{~A}_{1} \mathrm{~T}_{7}$ & 25.73 & 42.33 & 35.55 & 0.21 & 16.07 & 6.89 & $23.89 *(570.54)$ & $15.66 *(244.59)$ \\
\hline 8 & $\mathrm{~S}_{1} \mathrm{~A}_{2} \mathrm{~T}_{1}$ & 26.00 & 37.34 & 51.11 & 0.24 & 20.47 & 8.00 & $32.35 *(1046.73)$ & $20.24 *(408.90)$ \\
\hline 9 & $\mathrm{~S}_{1} \mathrm{~A}_{2} \mathrm{~T}_{2}$ & 24.00 & 36.33 & 42.22 & 0.25 & 22.17 & 8.55 & $30.60 *(937.13)$ & $19.01 *(360.99)$ \\
\hline 10 & $\mathrm{~S}_{1} \mathrm{~A}_{2} \mathrm{~T}_{3}$ & 26.53 & 41.33 & 40.00 & 0.24 & 22.11 & 8.37 & $29.69 *(885.15)$ & $18.28 *(334.71)$ \\
\hline 11 & $\mathrm{~S}_{1} \mathrm{~A}_{2} \mathrm{~T}_{4}$ & 27.67 & 41.67 & 35.55 & 0.26 & 19.23 & 7.68 & $26.16^{*}(685.56)$ & $16.54 *(273.32)$ \\
\hline 12 & $\mathrm{~S}_{1} \mathrm{~A}_{2} \mathrm{~T}_{5}$ & 26.87 & 39.33 & 44.45 & 0.26 & 19.65 & 7.24 & $29.55 *(873.29)$ & $17.96 *(322.17)$ \\
\hline 13 & $\mathrm{~S}_{1} \mathrm{~A}_{2} \mathrm{~T}_{6}$ & 31.60 & 45.34 & 33.33 & 0.21 & 16.67 & 6.70 & $23.53 *(556.84)$ & $14.93 *(223.27)$ \\
\hline 14 & $\mathrm{~S}_{1} \mathrm{~A}_{2} \mathrm{~T}_{7}$ & 33.27 & 47.66 & 31.11 & 0.15 & 14.99 & 6.22 & $21.58 *(466.33)$ & $13.93 *(193.53)$ \\
\hline 15 & $\mathrm{~S}_{1} \mathrm{~A}_{3} \mathrm{~T}_{1}$ & 36.80 & 44.67 & 44.45 & 0.14 & 14.98 & 7.17 & $25.81 *(666.65)$ & $17.87 *(319.08)$ \\
\hline 16 & $\mathrm{~S}_{1} \mathrm{~A}_{3} \mathrm{~T}_{2}$ & 35.47 & 41.00 & 37.78 & 0.21 & 16.90 & 7.99 & $25.28 *(640.29)$ & $17.39 *(302.30)$ \\
\hline 17 & $\mathrm{~S}_{1} \mathrm{~A}_{3} \mathrm{~T}_{3}$ & 37.40 & 44.33 & 35.55 & 0.16 & 16.27 & 7.62 & $24.04 *(577.96)$ & $16.46 *(270.34)$ \\
\hline 18 & $\mathrm{~S}_{1} \mathrm{~A}_{3} \mathrm{~T}_{4}$ & 37.94 & 45.34 & 31.11 & 0.14 & 14.60 & 6.91 & $21.30 *(454.25)$ & $14.68 *(215.35)$ \\
\hline 19 & $\mathrm{~S}_{1} \mathrm{~A}_{3} \mathrm{~T}_{5}$ & 37.20 & 47.00 & 37.78 & 0.14 & 15.30 & 6.33 & $24.05 *(579.32)$ & $15.47 *(238.70)$ \\
\hline 20 & $\mathrm{~S}_{1} \mathrm{~A}_{3} \mathrm{~T}_{6}$ & 40.27 & 51.00 & 28.90 & 0.11 & 13.86 & 5.58 & $20.00 *(400.01)$ & $12.72 *(161.52)$ \\
\hline 21 & $\mathrm{~S}_{1} \mathrm{~A}_{3} \mathrm{~T}_{7}$ & 43.20 & 55.67 & 24.45 & 0.11 & 12.17 & 4.95 & $17.24 *(297.41)$ & $11.03 *(121.15)$ \\
\hline 22 & $\mathrm{~S}_{2} \mathrm{~A}_{1} \mathrm{~T}_{1}$ & 13.53 & 26.34 & 82.22 & 0.66 & 26.05 & 9.62 & $46.29 *(2142.03)$ & $28.14 *(791.48)$ \\
\hline 23 & $\mathrm{~S}_{2} \mathrm{~A}_{1} \mathrm{~T}_{2}$ & 13.00 & 23.00 & 73.33 & 0.74 & 27.35 & 10.70 & $44.75 *(2003.42)$ & $28.00 *(784.27)$ \\
\hline 24 & $\mathrm{~S}_{2} \mathrm{~A}_{1} \mathrm{~T}_{3}$ & 14.67 & 24.33 & 73.33 & 0.60 & 27.26 & 10.31 & $44.69 *(1998.67)$ & $27.49 *(755.38)$ \\
\hline
\end{tabular}




\begin{tabular}{|c|c|c|c|c|c|c|c|c|c|}
\hline 25 & $\mathrm{~S}_{2} \mathrm{~A}_{1} \mathrm{~T}_{4}$ & 16.40 & 27.34 & 68.90 & 0.42 & 24.85 & 8.80 & $41.37 *(1710.92)$ & $24.64 *(606.16)$ \\
\hline 26 & $\mathrm{~S}_{2} \mathrm{~A}_{1} \mathrm{~T}_{5}$ & 16.07 & 28.66 & 75.56 & 0.42 & 23.89 & 8.55 & $42.44 *(1806.03)$ & $25.40 *(646.50)$ \\
\hline 27 & $\mathrm{~S}_{2} \mathrm{~A}_{1} \mathrm{~T}_{6}$ & 18.33 & 32.00 & 64.45 & 0.45 & 22.20 & 7.89 & $37.83 *(1430.94)$ & $22.57 *(508.97)$ \\
\hline 28 & $\mathrm{~S}_{2} \mathrm{~A}_{1} \mathrm{~T}_{7}$ & 19.93 & 35.33 & 57.78 & 0.33 & 21.20 & 7.21 & $34.98 *(1224.40)$ & $20.42 *(416.37)$ \\
\hline 29 & $\mathrm{~S}_{2} \mathrm{~A}_{2} \mathrm{~T}_{1}$ & 19.53 & 30.00 & 75.55 & 0.56 & 23.77 & 8.83 & $42.38 *(1795.72)$ & $25.85 *(667.58)$ \\
\hline 30 & $\mathrm{~S}_{2} \mathrm{~A}_{2} \mathrm{~T}_{2}$ & 18.53 & 28.33 & 66.67 & 0.60 & 24.67 & 10.53 & $40.54 *(1644.89)$ & $26.48 *(700.47)$ \\
\hline 31 & $\mathrm{~S}_{2} \mathrm{~A}_{2} \mathrm{~T}_{3}$ & 20.87 & 30.00 & 68.90 & 0.58 & 24.08 & 9.84 & $40.67 *(1658.92)$ & $26.01 *(678.26)$ \\
\hline 32 & $\mathrm{~S}_{2} \mathrm{~A}_{2} \mathrm{~T}_{4}$ & 21.27 & 30.33 & 73.33 & 0.50 & 23.15 & 8.46 & $41.18 *(1696.92)$ & $24.92 *(621.33)$ \\
\hline 33 & $\mathrm{~S}_{2} \mathrm{~A}_{2} \mathrm{~T}_{5}$ & 20.40 & 31.34 & 71.11 & 0.45 & 23.05 & 8.12 & $40.50 *(1639.88)$ & $24.04 *(577.17)$ \\
\hline 34 & $\mathrm{~S}_{2} \mathrm{~A}_{2} \mathrm{~T}_{6}$ & 22.47 & 35.00 & 55.55 & 0.41 & 21.12 & 7.53 & $34.25 *(1172.97)$ & $20.47 *(418.65)$ \\
\hline 35 & $\mathrm{~S}_{2} \mathrm{~A}_{2} \mathrm{~T}_{7}$ & 24.73 & 37.00 & 44.45 & 0.33 & 19.80 & 6.96 & $29.67 *(880.53)$ & $17.60 *(309.75)$ \\
\hline 36 & $\mathrm{~S}_{2} \mathrm{~A}_{3} \mathrm{~T}_{1}$ & 28.33 & 34.00 & 60.00 & 0.42 & 19.85 & 8.51 & $34.51 *(1193.87)$ & $22.59 *(510.35)$ \\
\hline 37 & $\mathrm{~S}_{2} \mathrm{~A}_{3} \mathrm{~T}_{2}$ & 27.00 & 31.67 & 57.78 & 0.44 & 21.15 & 10.13 & $34.97 *(1222.87)$ & $24.21 *(585.77)$ \\
\hline 38 & $\mathrm{~S}_{2} \mathrm{~A}_{3} \mathrm{~T}_{3}$ & 29.13 & 33.33 & 48.89 & 0.42 & 19.72 & 9.61 & $30.98 *(962.18)$ & $21.66 *(470.11)$ \\
\hline 39 & $\mathrm{~S}_{2} \mathrm{~A}_{3} \mathrm{~T}_{4}$ & 29.87 & 35.00 & 44.45 & 0.41 & 17.59 & 8.25 & $27.95 *(781.25)$ & $19.17 *(367.07)$ \\
\hline 40 & $\mathrm{~S}_{2} \mathrm{~A}_{3} \mathrm{~T}_{5}$ & 32.00 & 35.00 & 48.89 & 0.41 & 17.64 & 7.90 & $29.31 *(862.45)$ & $19.63 *(386.25)$ \\
\hline 41 & $\mathrm{~S}_{2} \mathrm{~A}_{3} \mathrm{~T}_{6}$ & 36.67 & 39.00 & 35.56 & 0.40 & 15.79 & 7.06 & $23.70 *(562.14)$ & $15.85 *(250.81)$ \\
\hline 42 & $\mathrm{~S}_{2} \mathrm{~A}_{3} \mathrm{~T}_{7}$ & 39.20 & 39.67 & 31.11 & 0.34 & 14.47 & 6.69 & $21.20 *(449.67)$ & $14.44 *(208.39)$ \\
\hline \multirow{2}{*}{\multicolumn{2}{|c|}{$\begin{array}{l}\text { SE }(m) \\
\text { CD at } 5 \%\end{array}$}} & 0.212 & N/A & N/A & 0.007 & 0.248 & 0.119 & N/A & N/A \\
\hline & & 0.597 & N/A & N/A & 0.019 & 0.698 & 0.335 & N/A & N/A \\
\hline
\end{tabular}

* Transformed values

$\mathrm{S}_{1}$ :Flat position;

$\mathrm{S}_{2:}$ Stalk end up position;

$\mathrm{A}_{1}:$ Freshly extracted stones

$\mathrm{A}_{2}: 10$ days after extraction

$\mathrm{A}_{3}: 20$ days after extraction

$\mathrm{T}_{1}: \mathrm{GA}-100 \mathrm{ppm}$

$\mathrm{T}_{2}: \mathrm{GA}_{3}-200 \mathrm{ppm}$

$\mathrm{T}_{3}-\mathrm{KNO}_{3}-1 \mathrm{ppm}$

$\mathrm{T}_{4}: \mathrm{KNO}_{3}-2 \mathrm{ppm}$

$\mathrm{T}_{5}$ : cow dung slurry

$\mathrm{T}_{6}$ : water

$\mathrm{T}_{7}$ : control (without treatments) 
In the current trial, maximum Seedling Vigour Index-I was observed when mango stones which were treated with $\mathrm{GA}_{3} 100 \mathrm{ppm}$ followed by $\mathrm{GA}_{3} 200 \mathrm{ppm}$ whereas minimum was noticed in control. This can be ascribed to the cumulative effect of higher shoot length, root length and germination percentage under $\mathrm{GA}_{3}$ treatments. These results are in agreement with an earlier report by Patil et al., (2012) in citrus.

\section{Interaction effect}

The freshly extracted mango stones which were soaked in $200 \mathrm{ppm} \mathrm{GA}_{3}$ solution and sown in plumule up position recorded the least number of days for initiation of germination and $50 \%$ germination, highest rate of germination, seedling length and dry weight whereas freshly extracted mango stones which were soaked in $100 \mathrm{ppm} \mathrm{GA}_{3}$ solution recorded the highest germination, seedling vigour index- I and seedling vigour index- II. As the interaction effect of the factors viz., sowing positions, age of stones after extraction from the fruit and pre-sowing treatments on germination of mango stones concerned, there were no significant effect obtained for days taken for $50 \%$ germination, germination percentage, Seedling Vigour Index- I and Seedling Vigour Index- II (Table 2).

In conclusion, from the present investigation, it is evident that the freshly extracted mango stones which were soaked in $200 \mathrm{ppm} \mathrm{GA}_{3}$ solution and sown in stalk-end up position recorded the least number of days for initiation of germination, and $50 \%$ germination, highest rate of germination, seedling length and dry weight whereas the stones soaked in $100 \mathrm{ppm} \mathrm{GA}_{3}$ solution recorded the highest germination, seedling vigour index- I and seedling vigour index- II. The pre-sowing treatments, sowing positions and age of stones need to be taken into consideration to attain a noticeable difference in enhancing the germination, rapid emergence, stimulating the growth and vigour of seedlings.

\section{Acknowledgements}

The authors are thankful to Dr.Babu Mathew, former Professor and Head of the Instructional Farm, College of Agriculture, Vellayani for providing the necessary facilities for the research programme and Dr.Vijayaraghava Kumar, Professor and Head, Department of Agricultural Statistics for data analysis and technical assistance.

\section{References}

Abdul- Baki, A. A. and Anderson, J. D. 1973. Vigour determination of soybean seed by multiple criteria. Crop Science. 13: 630-633.

Bewley, J. D. 1997. Seed germination and dormancy. Plant Cell. 9:1055-1066.

Chaudhari, P. M. and Patel, B. N. 2012. Effect of pre-sowing treatments, sowing position and duration on germination of mango stones. Bioinfolet. 9: 277-279.

Copeland, L. O. and Mcdonald, M. B. 1995. Principles of Seed Science and Technology, 4th edn. Norwell, Massachusetts. Kluwer Academic Publishers. Annals of Botany. 89: 488.

Diaz, D. H. and Martin, G. C. 1971. Peach seed dormancy in relation to inhibitors and applied growth substance. Journal of American Society of Horticulture Science. 97: 651-654.

Garner, R. J. and Chaudhri, S. A. 1976. The propagation of tropical fruit trees. Common Wealth Bureau of Horticulture and Plantation Crops. East Malling. Maidstone. Kent. 28 p.

Hammed, A. L., Aliyu, O. M., Dada, E. K., and Egbewale, S. O. 2014. Cultivar 
type and nut-sowing orientation influence germination and plant vigour in Cashew (Anacardium occidentale L.). International Journal of Fruit Science. 14:69-80.

Kolekar, S. N., Kadam, A. S., and Gend, D. G. 2017. Effect of different organics and chemicals treatments on germination, growth and success of softwood grafting in mango during nursery stage. International Journal of Chemical Studies. 5: 880-884.

Kumar, H. S., Swamy, G. S. K., Patil, C. P., Kanmadi, V. C., and Kumar, P. 2008a. Effect of pre-soaking treatments on the success of softwood grafting and growth of mango grafts. Karnataka Journal of Agricultural Sciences. 21:471-472.

Kumar, Y. H. S., Hippargi, K., Swamy, G. S. K., Hemavathi, G. N., Nadukeri, S., and Kanthraju, Y. 2018b. Studies on seed viability and its effects on germination, growth and graft-take in medicinal fruit plant of Jamun. Journal of Pharmacognosy and Phytochemistry. 5: 471-474.

Lay, P., Basvaraju, G.V., Sarika, G., and Amrutha, N. 2013. Effect of seed treatments to enhance seed quality of papaya (Carica papaya L.) Cv. Surya. Greener Journal of Biomedical Health Science. 2: 221-225.

Muralidhara, B. M., Reddy, Y. T. N., Akshita, H. J., and Srilatha, V. 2015. Effect of pre sowing treatments on germination, growth and vigour of polyembryonic mango seedlings. Environment and Ecology. 33(3): 1014-1018.

Paleg, L. G. 1960. Physiological effects of gibberellic acid II. Plant physiology. 35: 902-906.

Panse, V.G. and Sukhatme, P.V. 1967. Statistical Methods for Agricultural Workers. ICAR, New Delhi.

Patel, R. J., Ahlawat, T. R., Singh, A., Momin, S. K., and Gavri, C. 2016. Effect of pre-sowing treatments on stone germination and shoot growth of mango (Mangifera indica L.) seedlings. International Journal of Agricultural Scences. 8(52): 24372440.

Patil S. S. and Krishna, A. 2016. Influence of seed moisture content on seed germination and quality in canes. Journal of Plant Science Research. 3(2):1-4.

Patil, S. R., Sonkamble, A.M., and Khobragade, H. M. 2012. Influence of some growth regulators on germination and growth of Rangpur lime (Citrus limonia O.) seeds under shade net conditions. Green Farming. 3(6): 690-693.

Shaban, A. E. A. 2010. Improving seed germination and seedling growth of some mango rootstocks. American Eurasian Journal of Agriculture and Environmental Science.7(5): 535-541.

Shalini, P., Bagde, T. R., and Bhati, B. 1999. Growth of mango (Mangifera indica L.) seedlings as influenced by stone treatment. Journal of Soils and Crops. 9(2): 227-230.

\section{How to cite this article:}

Reshma, U.R. and Simi, S. 2019. Effect of Pre-Sowing Treatments, Sowing Positions and Age of Stones after Extraction on Germination of Mango. Int.J.Curr.Microbiol.App.Sci. 8(04): 2565-2573. doi: https://doi.org/10.20546/ijcmas.2019.804.298 